\title{
Цифровая трансформация политических отношений на Дальнем Востоке: проблемы и перспективы
}

В последнее десятилетие во всем мире при проектировании и развитии социально-экономических систем приобретает актуальность цифровизация политических процессов. Примером могут служить нетрадиционные формы взаимодействия между властью и гражданами - 90\% всех выводимых государственных услуг предоставляются посредством новейших цифровых технологий (электронное правительство, избирательный процесс, технологии блокчейн, искусственный интеллект, робототехника, большие данные и пр.)

На сегодняшний день сущность и процессы, сопровождающие цифровизацию, вызывают огромный интерес у отечественных и зарубежных исследователей современного мира. С приходом технологий, "которые в основном используются для целей планирования, мониторинга и оценки результатов деятельности органов власти" [32, с. 82; 5, с. 6], происходит цифрровая трансформация всех сфрер российского государства и общества [3, c. 14].

Несмотря на негативный опыт во время эпидемии Covid-19, цифрровизация позволила государственному аппарату обратить внимание граждан на возможности новейших цифровых технологий (оптимизация деятельности общественных структур). Принимаемые политические меры приводят к определённым позитивным тенденциям и результатам, но вместе с тем остается целый ряд малоисследованных проблем, которые за собой несёт современный феномен. По расчётам Мирового банка специалисты отмечают перспективы замещения людей роботами, к 2033 г. под влиянием цифровизации в США могут исчезнуть $47 \%$ рабочих мест, имеющихся на момент 2018 г., в Китае $-77 \%$, что приведет к массовой безработице [32, с. 83].

Следуя тенденциям мирового сообщества, в стране и регионах России разрабатываются и реализуются различные региональные програллы и проекты в области развития инфборлационньх технологий. В рамках политики государства создано Министерство цифрового развития, связи и массовых коммуникаций Российской Федерации, на региональном уровне ДФО - Министерство цифрового развития и связи Приморского, Хабаровского, Забайкальского краев, Сахалинской, Амурской областей и др. для реализации национальной программы "Цифровая экономика".

Несмотря на множество исследований по теме цифровизации международного и государственного масштаба, остается недостаточно исследованной проблема рассмотрения и оценки цифровой трансформации на региональнол уровне $[5 ; 6 ; 10 ; 12 ; 13 ; 30 ; 31]$. Освоение Дальнего Востока исторически обусловлено необходимостью обеспечения национальной безопасности страны (5-я армия, Тихоокеанский фрлот и пр.). Так как российский Дальний Восток является частью Азиатско-Тихоокеанского региона, в приоритете стоит вопрос взаимоотношений с соседними странами. С одними государствами обозначены четкие позиции тесного партнерства, с другими - продолжительный конфоликт или разногласия, вытекающие из истории взаимоотношений и территориаль-

\section{(C) Потанина О. В., 2021}

ПОТАНИНА Ольга Валериевна, специалист отдела организации научно-исследовательской работы Департамента научно-исследовательской работы Владивостокского государственного университета экономики и сервиса (ә. Владивосток). E-mail: potaninaolgav@gmail.com 
ного вопроса. В АТР ведется непрекращающаяся борьба за региональное лидерство. Наличие сильных соседей заставляет нашу страну укреплять свои позиции и, в частности, Дальний Восток, который характеризуется таким преимуществом, как геополитическое расположение. Повышение уровня региона в экономическом и политическом плане ведет к обострению борьбы за региональное лидерство. В Российском государстве разработаны программы [23], которые призваны в перспективе уделять немалое внимание к Дальнему Востоку (стратегии развития, дальневосточный гектар, демографическое развитие и пр.). Цель государственной политики - ускорить экономическое развитие и повысить качество жизни населения Дальнего Востока [21].

Высокий уровень территориального инновационного развития социально-экономических, политических и других сфрер за счет внедрения новейших технологий способствует формированию благоприятной среды для общества и обеспечивает устойчивое развитие региона.

Методология и методы исследования основаны на системном подходе. Теоретическую базу составили отечественные исследовательские труды, в которых рассматривается цифровая трансформация на региональном и муниципальном уровнях. Общенаучную группу методов познания исследования составили анализ, синтез, индукция и дедукция, а также метод аналогии как общенаучные методы познания. В рамках частнонаучных методов познания использовались историко-политический метод для рассмотрения изменений общественно-политических практик и метод политического моделирования, позволяющий спрогнозировать среднесрочные перспективы трансформации региона, а также группа специальных методов: контент-анализ научной литературы по теме исследования, сопоставительный анализ, анализ и ранжирование данных Индекса "Цифровая Россия".

Материалами исследования послужили документы: сформулированная Министерством цифрового развития, связи и массовых коммуникаций Российской Федерации Программа "Цифровая экономика Российской Федерации", Стратегия развития информационного общества в Российской Федерации на 2017-2030 гг., Национальная программа социально-экономического развития Дальнего Востока на период до 2024 г. и на перспективу до 2035 г., Стратегия социально-экономического развития Дальнего Востока и Байкальского региона на период до 2025 г., расчеты Индекса "Цифровая Россия" для регионов РФ.

Разработанность темы. По мнению автора, если системно посмотреть на изученную литературу и источники по исследуемой проблематике, то можно разбить условно их на следующие блоки:

"Трансбборлаиия внутригосударственных политических отношений". В данный блок стоит выделить работы авторов, которые изучают цифровизацию современного общества, влияние цифровых технологий на политический процесс в общем, тенденциях, рисках и угрозах данного феномена, а также внедрение новейших технологий и цифровую трансформацию в рамках одной страны. Данное направление представлено такими отечественными исследователями, как А. Ю. Мамычев, М. Ю. Павлютенкова, И. А. Родионова, С. В. Володенков, Я. Р. Игнатовский, Н. Лопатова, Е. В. Бродовская, С. В. Савина, А. А. Шпакова, Т. В. Фомичева, В. И. Катаева, Е. И. Добролюбова, Я. В. Гайворонская и др. [2-7; 14; 16; 17; 24; 25; 27; 32; 36].

"Цифровая трансбормация политических отношений, разворачиваюшихся на международном уровне". Авторы, которые берут за основу две и более страны или мировой масштаб, оценивают внедрение новейших цифровых технологий [37], проводят сравнительный анализ, изучают рейтинги развитых и развивающихся стран, а также влияние данного феномена на общество в результате внедрения в политический процесс. Данное направление представлено следующими авторами: А. Е. Коньков, В.В.Коровкин, В. К. Белозеров, Н. Лопатова, А. Ю. Мамычев, Е. Е. Фролова, А. А. Ким, И. А. Сальников, В. В. Варюхин, Ю. А. Малахова, В. Ю. Черемных, Л. С. Яковлев, Н. В. Соловьева и др. $[1 ; 9 ; 11 ; 14 ; 17 ; 28 ; 29 ; 34]$.

Немногие авторы изучают процессы цифровизации в рамках одного региона или субъекта страны. Для изучения проблемного вопроса данной статьи необходимо выделить отдельный блок - "Цифровизация регионального уровня". Т. В. Коняева, Е. И. Добролюбова, В. Н. Тюшняков, О. С. Сухарев, 
Табл. 1. Предположительные уровни цифрового разрыва

\begin{tabular}{|c|c|c|c|}
\hline Уровень & Примечание & Сущность & $\begin{array}{l}\text { Этап цифровой трансформации } \\
\text { государственного управления }\end{array}$ \\
\hline Доступ к Интернету & $\begin{array}{l}\text { Создание условий } \\
\text { доступа к сети Интер- } \\
\text { нет, в развитых стра- } \\
\text { нах переход на 5G, в } \\
\text { регионах России не } \\
\text { везде доступно 4G }\end{array}$ & \begin{tabular}{|l|} 
Официальные сайты \\
организаций, соцсети, \\
приложения на теле- \\
фоне, мессенджеры \\
и многое другое ото- \\
бражают "поверхност- \\
ную сущность" - что \\
может видеть и чем \\
пользоваться каждый \\
гражданин. Однако \\
в силу какой-либо \\
причины (город-село, \\
возрастной, и пр.) \\
происходит цифровой \\
разрыв
\end{tabular} & $\begin{array}{l}\text { Оцифровка, электронное прави- } \\
\text { тельство }\end{array}$ \\
\hline Цифровая система & $\begin{array}{l}\text { Создание разноо- } \\
\text { бразных цифровых } \\
\text { решений, цифровых } \\
\text { платформ, большие } \\
\text { данные, благодаря } \\
\text { которым образуется } \\
\text { единая цифровая } \\
\text { сеть цифровизации }\end{array}$ & $\begin{array}{l}\text { "Внутренняя сущ- } \\
\text { ность" наполнена } \\
\text { благодаря новейшим } \\
\text { цифрровым техноло- } \\
\text { гиям }\end{array}$ & $\begin{array}{l}\text { Активное использование больших } \\
\text { данных -принцип однократного } \\
\text { предоставления данных граждана- } \\
\text { ми и организациями для дальней- } \\
\text { шего использования }\end{array}$ \\
\hline Цифровая сеть & $\begin{array}{l}\text { Цифровой суверени- } \\
\text { тет страны }\end{array}$ & $\begin{array}{l}\text { Цифровизация } \\
\text { страны на междуна- } \\
\text { родном уровне }\end{array}$ & $\begin{array}{l}\text { Полностью цифровое государ- } \\
\text { ственное управление }\end{array}$ \\
\hline
\end{tabular}

Источник: составлено автором по [6; 10; 12; 13; 26; 27; 30; 31; 32; 35, с. 402].

Е. А. Кранзеева, Л. В. Лапидус и др. работают в данном направлении [5; 6; $10 ; 12 ; 13 ; 31 ; 30]$.

Основная часть. В каждом из вышеуказанных блоков существуют свои способы оценки уровня цифровизации. Разработаны различные индексы - ИКТ (Индекс развития информационно-коммуникационных технологий), DESI (Индекс цифровой экономики и общества Европейского союза), DECA (готовность страны к цифровой экономике - Digital Economy Country Assessment), Национальный индекс развития циоровой экономики для межстранового сопоставления, Госкорпорация POCATOM и пр. Что касается оценки уровня цифровой трансформации регионов, в рамках исследуемого вопроса, хотелось бы отметить СКОЛКОВО - Цифровая жизнь российских мегаполисов, Цифровая Россия и Национальный рейтинг цифровизации регионов Российской Федерации и др. [13, с. 7].

Центр финансовых инноваций и безналичной экономики Московской школы управления СКОЛКОВО, согласно утвержденной государственной программе [22], для измерения повседневной цифровой жизни предлагает Индекс "Цифровая Россия" в целях реализации развития информационного общества $[8 ; 19]$. Данная система оценки индекса имеет семь показателей цифровой трансформации, составляющих индекс измерения региона, каждый из которых предполагает свои направления. По мнению автора, небольшое количество показателей является положительным моментом: видны сильные отрасли и можно сделать упор на развитие слабых. По каждому из показателей существуют иифровое предложение и иифровой спрос. Отдельным измерением является разрыв между ними, указывающий на слабые области, которым необходимо уделить внимание.

При рассмотрении данной проблематики в научной литературе, посвященной изучению процессов цифровизации в регионах России [6, с. 42], можно выделить три уровня цифрового разрыва (табл. 1). 
Табл.2. Индекс цифровизации Дальневосточного федерального округа

\begin{tabular}{|l|c|c|c|}
\hline \multicolumn{1}{|c|}{ Субъект РФ } & Индекс & $\begin{array}{c}\text { Место в общем } \\
\text { рейтинге РФ (2018 г.) }\end{array}$ & $\begin{array}{c}\text { Место в ДФО } \\
\text { (2018 г.) }\end{array}$ \\
\hline Республика Саха (Якутия) & 71,11 & 18 & 1 \\
\hline Сахалинская область & 64,35 & 33 & 2 \\
\hline Приморский край & 59,96 & 41 & 3 \\
\hline Хабаровский край & 59,67 & 42 & 4 \\
\hline Амурская область & 56,82 & 47 & 6 \\
\hline Камчатский край & 52,91 & 53 & 7 \\
\hline Магаданская область & 45,71 & 72 & 8 \\
\hline Забайкальский край & 44,75 & 74 & 9 \\
\hline Республика Бурятия & 43,65 & 77 & 10 \\
\hline Чукотский автономный округ & 41,64 & 80 & 11 \\
\hline Еврейская автономная область & 39,76 & 84 & 5 \\
\hline
\end{tabular}

Источник: составлено автором по [8].

Исходя из данных таблицы 1, по мнению автора, российские регионы находятся на разных уровнях цифрового разрыва, большая часть которых на первом, меньшая - на стадии перехода с первого на второй уровень.

Обращаясь к современным исследованиям, о существующем цифровом разрыве в своих работах пишут такие отечественные авторы, как Г. А. Малышева, А. А. Мушта, Т. В. Растимешина и др. Исследователи делают выводы о проблеме цифрового неравенства, где низшей точкой отсчета считается компьютерная неграмотность граждан [15, с. 150], а верхняя - разрыв между сфрерами "принятия политических решений и технологических" нововведений $[18$, c. 42]. Стоит отметить, только некоторые учёные говорят о "цифровой зрелости" региона или о сокращении по возможности минимизации данного "разрыва" между субъектами внутри одной страны.

Для прогнозирования и повышения цифровой зрелости региона необходимо учитывать его специфические особенности [30, с. 47], уровень развития информационного общества с учетом начального потенциала развития конкретных субъектов и другие фракторы [6, с. 46]. Информационной базой исследования автора статьи являются разработанные данные индекса "Цифровая Россия" [8], региональные программы и проекты в области развития информащионных технологий. ДФО выделен из общего числа 85 регионов, разделен на 11 субъектов. Автором проанализированы позиции в рейтинге за 2018 г. и ранжированы по уровню развития цифровой трансформации. Диапазон значений индекса по России составляет от 39,74 до 77,03, где максимальное значение принадлежит Москве, стоящей на 1 месте в общероссийском рейтинге по уровню цифрровизащии, а самым отстающим регионом является Республика Тыва - 85 место. Что касается Дальневосточного феедерального округа, значения индекса "Цифровая Россия" представлены в таблице 2.

Таким образом, лидирующую позицию занимает Республика Саха (Якутия) - 18 место по уровню цифровизации в общем рейтинге по России, самый низкий показатель индекса цифровизации среди регионов ДФО принадлежит Еврейской автономной области - практически самое последнее место (84 из возможных 85). Согласно вышеуказанному индексу можно выявить диспропорции развития цифрового показателя среди субъектов в рамках одного федерального округа.

Благодаря специально разработанным и реализованным проектам в рамках одного региона России, цели и задачи которого согласованы [33], мож- 
но сделать выводы о том, что, если уделить внимание отстающим субъектам, региональный дисбаланс можно в существенной степени устранить [10, с. 77].

Что касается нового подхода к цифрровизации госорганов на текущий год и период 2022-2023 гг., премьер-министр РФ М. Мишустин в апреле 2021 г. подписал Постановление Правительства РФ, согласно которому:

- назначены руководители цифровой трансформации во всех регионах России, ответственные за цифровую трансформацию региона как ключевого показателя их деятельности [20];

- утвержден алгоритм расчёта показателей "цифровой зрелости" региона и прослеживается эфрфективность работы губернаторов;

- появилась возможность определения уровня внедренных цифровых технологий, оцифрованных процессов и операций в организации, сфрормированных цифрровых навыков и компетенции персонала и пр.

Выводы. Национальная программа "Цифровая экономика" является одним из основных документов, раскрывающих направленность государственной политики на цифрровую трансформацию. Период планирования до 2024 г. (и на перспективу до 2035 г.) в соответствии с Указом Президента РФ можно оценить как среднесрочную перспективу развития регионов. В рамках концепции электронного правительства отдельной подпрограммой выделен раздел "Цифровое государственное управление", согласно которому формируется единая национальная цифровая сеть сореры государственного управления, разработки и принятия стратегических решений [5, с. 94].

Автор статьи разделяет позицию Т. В. Коняевой, Е. И. Добролюбовой, В. Н. Тюшнякова и др., которые считают, что каждый из регионов Российской Федерации, в том числе и Дальний Восток, представляет собой самостоятельную единицу в большом уравнении цифровизации страны, которая имеет свои особенности, требующие формирования собственного подхода к цифровой трансорормации [27, с. 445]. В то же время О. С. Сухарев считает, что нет необходимости вообще измерять "цифровую зрелость" региона, поскольку данный показатель напрямую зависит от степени выполнения поставленных задач согласно Национальному проекту или федеральной программе по цифровизации [30, с. 55].

По мнению автора, для достижения цифровой зрелости Дальневосточному региону необходимы:

- комплексный подход к созданию правовых, организационных и технологических условий государственной поддержки [6];

- высокая компетентность региональных и муниципальных властей, отвечающих за системную реализацию программ цифровой трансформации [26, c. 555];

- сокращение цифрового разрыва с помощью применения новейших цифровых и информационных технологий во всех сфрерах общественной жизни;

- повышение качества управления (внедрение методики, снижающей затраты на обучение, применение и пр.) [38, с. 529], подготовка соответствующего кадрового состава (развитие человеческого капитала) и внедрение образовательных программ для обучения граждан цифровым навыкам [14, с. 27];

В большей части субъектов РФ цифровая трансформация началась задолго до 2018 г. Благодаря высоким темпам развития новейших цифровых технологий в мировом масштабе ежегодно расширяется перечень поставленных задач и увеличивается сложность внедрения инноваций в государственное управление страны. Так как государственные программы рассчитаны на среднесрочную перспективу, можно предположить, что индекс цифрового развития и цифровая зрелость ДФО будут ежегодно расти, в то время как общий темп развития цифровой трансформации останется невысоким.

Ведется интенсивная работа по развитию региона с целью цифровой трансформации. Разрабатываются способы оценки цифровизации. Для повышения цифрового рейтинга целого региона России необходимо устранение причин, приводящих к отсталости субъекта РФ. Однако остается открытым вопрос, насколько степень измерения каждого из способов является достоверной, необходимо время для подтверждения или опровержения прогнозов, так как оценка может являться условной. 
Тема предпринятого исследования актуальна. Научная новизна данного исследования заключается в рассмотрении цифровизации на региональном уровне, использовании новейших цифровых технологий как инструментов во властно-управленческой деятельности, применении комплексного подхода. Автор считает, что цифровизация России напрямую зависит от уровня цифровой трансформации регионов. Принципиально важно рассмотреть, выделить, проанализировать лидирующие и отстающие регионы РФ, выявить и устранить причины наименьшего цифрового спроса в отдельной отрасли субъектов РФ, определить наиболее важный перечень стратегических решений государственного аппарата в сфере управления цифровой активностью. Все перечисленные вопросы необходимо решить России для повышения позиции в рейтинге цифрровизации международного уровня.

Именно в соответствии с вышеизложенным актуализируется необходимость в более детальном изучении следующих вопросов, направленных на повышение уровня цифровизации региона, таких как устранение причин возникающих проблем и обоснование методов их решения, привлечение инвесторов для финансирования региональных проектов, выделение средств из федерального бюджета для реализации проектов только высокой значимости и др.

В целом при рассмотрении цифровой трансформации регионального уровня отмечена необходимость интегрированного внедрения новейших цифрровых технологий. Планируемые госаппаратом мероприятия в среднесрочной перспективе направлены на повышение уровня взаимодействия между гражданами и государственным аппаратом управления в политической сфере для достижения цифровой зрелости.

\section{Литература}

1. Белозеров В.К. Международная политическая коммуникация в условиях цифрровизации мирового развития // Контуры глобальных трансформаций: политика, экономика, право. 2020. Т.13. № 2. С. 177-194.

2. Бродовская Е.В. Цифровые граждане, цифровое гражданство и цифровая гражданственность // Власть. 2019. Т. 27. № 4. С. 65-69.

3. Володенков С.В. Трансформация современных политических процессов в условиях цифровизации общества: ключевые сценарии // Контуры глобальных трансформаций: политика, экономика, право. 2020. Т.13. № 2. С. 6-24.

4. Гайворонская Я.В. Цифра, культура и выборы // Представительная власть XXI век: законодательство, комментарии, проблемы. 2021. № 3(186). С. 24-28.

5. Цифровое будущее государственного управления по результатам / Е.И. Добролюбова, В.Н. Южаков, А.А. Ефремов [и др.]. М.: «Дело» РАНХиГС, 2019. 114 с.

6. Добролюбова Е.И. Оценка цифровой зрелости государственного управления // Информащионное общество. 2021. № 2. С. 37-52.

7. Игнатовский Я.Р. Роль цифровизации в трансеормащии российского политического протеста // Власть. 2021. Т. 29. № 1. С. 84-89. DOI: 10.31171/vlast.v29i1.7917

8. Индекс «Цифровая Россия». - Текст: электронный // Бизнес-школа управления СКОЛКОВО: [сайт]. URL: https://www.skolkovo.ru/researches/indeks-cifrovayarossiya/ (дата обращения: 18.08.2021).

9. Коньков А.Е. Политический дискурс в условиях расширения цифрового пространства // Россия: тенденции и перспективы развития. 2019. №14-1. С. 119-121.

10. Коняева Т.В. Исследование региональных диспропорций в развитии цифровой экономики Приволжского федерального округа // Экономика и бизнес: теория и практика. 2019. № 7. C. 76-80. DOI: 10.24411/2411-0450-2019-11080.

11. Коровкин В.В. Национальные программы цифровой экономики стран Ближнего Востока // ArsAdministrandi. 2019. T. 11. № 1. C. 151-175. DOI: 10.17072/22189173-2019-1-151-175.

12. Реактивные социальные и политические взаимодействия в инновационных процессах регионов России / Е.А. Кранзеева, Е.В. Головацкий, А.В. Орлова [и др.] // Власть и управление на Востоке России. 2021. № 2 (95). C. 86-102. DOI: 10.22394/18184049-2021-95-2-86-102.

13. Лапидус Л.В. Анализ методик оценки уровня цифрровизации через призму приоритетности для развития российских регионов // Международная ежегодная научная конференция Ломоносовские чтения-2019. Секция экономических наук. Экономические отношения в условиях цифровой трансформации: сборник тезисов выступлений / под ред. М. В. Артамонова, С. Н. Бобылев, Г. И. Брялина [и др.]. М., 2019. Т. 1. C. $6-9$. 
14. Лопатова Н. Международный опыт формирования цифрового правительства // Наука и инноващии. 2019. № 5. С. 24-28.

15. Малышева Г.А. О социально-политических вызовах и рисках цифровизации российского общества // Власть. 2018. № 1. С. 40-46.

16. Мамычев А.Ю., Петрова Д.А. Биополитические и цифровые тенденции развития политико-правовых практик в период пандемии // Территория новых возможностей. Вестник Владивостокского государственного университета экономики и сервиса. 2020. T. 12. № 4. C. 18-29. DOI: 10.24866/VVSU/2073-3984/2020-4/018-029.

17. Мамычев А.Ю., Фролова Е.Е., Ким А.А. «Будущее» как аттрактор современных политико-правовых и социально- экономических трансформаций: обзор основных проблем и подходов // Advances in Law Studies. 2020. Vol. 8: Special issue. P. 3-17.

18. Мушта А.А., Растимешина Т.В. Информационно-аналитическая компетентность в контуре государственного управления: проблемные аспекты и пути совершенствования // Экономические и социально-гуманитарные исследования. 2019. № 2 (22). C. $147-154$.

19. О Стратегии развития информационного общества в Российской Федерации на 2017-2030 годы: Указ Президента Российской Федерации от 9 мая 2017 г. № 203. - Текст: электронный // CПС КонсультантПлюс: [сайт]. URL: http://www.consultant.ru/ document/cons_doc_LAW_216363/ (дата обращения: 20.08.2021).

20. Об оценке эффективности деятельности высших должностных лиц (руководителей высших исполнительных органов государственной власти) субъектов Российской Федеращии и деятельности органов исполнительной власти субъектов Российской Федерации: Указ Президента РФ от 4 февраля 2021 г. № 68. - Текст: электронный // Официальный интернет-портал правовой информации. URL: http://publication.pravo. gov.ru/Document/View/0001202102040027?index=0\&rangeSize=1 (дата обращения: 20.08.2021).

21. Об утверждении Национальной программы социально-экономического развития Дальнего Востока на период до 2024 г. и на перспективу до 2035 г.: распоряжение Правительства РФ от 24 сентября 2020 г. № 2464-р. - Текст: электронный // ГАРАНТ. PУ: [сайт]. URL: https://www.garant.ru/products/ipo/prime/doc/74587526/ (дата обращения: 20.08.2021).

22. Об утверждении программы «Цифровая экономика Российской Федерации»: распоряжение Правительства Российской Федерации от 28 июля 2017 г. № 1632-p. Текст: электронный // ГАРАНТ.PУ: [сайт]. URL: http://base.garant.ru/71734878/(дата обращения: 20.08.2021).

23. Об утверждении Стратегии социально-экономического развития Дальнего Востока и Байкальского региона на период до 2025 года: распоряжение Правительства РФ от 28 декабря 2009 года № 2094-p. - Текст: электронный // ГАРАНТ.РУ: [сайт]. URL: https://www.garant.ru/products/ipo/prime/doc/6632462/ (дата обращения: 20.08.2021).

24. Павлютенкова М.Ю. Электронное правительство vs цифровое правительство в контексте цифровой трансформации. - Текст: электронный // Мониторинг общественного мнения: Экономические и социальные перемены. - 2019. № 5. С. 120-135. DOI: 10.14515/monitoring.2019.5.07

25. Родионова И.А., Кокуйцева Т.В., Харламов М.М. Особенности развития цифровизации в Российской Федерации и в развитых странах мира: анализ позиций в международных рейтингах // Экономические отношения. 2020. Т. 10. № 2. С. 381-394. DOI: $10.18334 /$ eo.10.2.110130.

26. Рождественская И.А. Цирровая зрелость российских регионов: проблемы оценки // Самоуправление. 2021. № 3 (125). С.553-555.

27. Савина С.В. Развитие цифровых технологий в России // Самоуправление. 2021. №2 (221). C.445-449.

28. Сальников И.А., Варюхин В.В., Малахова Ю.А. Новая стратегия развития информационного общества в России: новые технологии, новые требования, новые перспективы // Ученые записки Санкт-Петербургского имени В. Б. Бобкова фрилиала Российской таможенной академии. 2017. № 2 (62). С. 118-124.

29. Соловьева Н. В. Стратегия развития информационного общества как основа формирования единого информационного пространства // Право и государство: теория и практика. 2019. № 4. С. 104-109.

30. Сухарев О.С. Оценка институтов регионального развития и эффективности исполнительной власти субъектов Российской Федерации. - Текст: электронный // Федерализм. 2021. № 2. C. 43-64. DOI: 10.21686/2073-1051-2021-2-43-64.

31. Тюшняков В.Н. Цифровая трансформация субъектов Российской Федерации // Управление в экономических и социальных системах: электронный научный журнал. 2020. № 2 (4). C. 41-46. URL: http://www.journal-mes.ru (дата обращения: 22.08.2021).

32. Фомичева Т.В., Катаева В.И. Ценности россиян в контексте цифровизации российской экономики // Уровень жизни населения регионов России. 2019. № 2(212). C. $80-84$. 
33. Цифровая экономика РФ. - Текст: электронный // Министерство цифрового развития, связи и массовых коммуникаций Российской Федерации: [сайт]. URL: https://digital.gov.ru/ru/activity/directions/858/ (дата обращения: 19.08.2021).

34. Черемных В.Ю., Яковлев Л.С. Электронное правительство: модели и перспективы // Вестник ПАГС. 2017. №1. С. 68-74.

35. Шестопал С.С., Мамычев А.Ю. Суверенитет в глобальном цифровом измерении: современные тренды // Балтийский гуманитарный журнал. 2020. Т. 9. № 1(30). C. 398-403. DOI: 10.26140/bgz3-2020-0901-0098.

36. Шпакова А.А., Горюнова С.А. Стратегические программы по цифровизации экономики Южной Кореи // ArsAdministrandi (Искусство управления). 2021. Т. 13. № 2. C. 260-284. DOI: 10.17072/2218-9173-2021-2-260-284.

37. Hudson V.M. Artificial Intelligence and International Politics. New York: Routledge, 2019. 422 p. DOI: 10.4324/9780429033575.

38. Momeni M.A., Yaghoubi S., Aliha M.R.M. An Optimal Control Model for Analyzing Quality Investment in the Project Management // Computers \& Industrial Engineering. 2019. Vol. 129. P. 529-544.

\section{Транслитерация по ГОСТ 7.79-2000 Система Б}

1. Belozerov V.K. Mezhdunarodnaya politicheskaya kommunikatsiya v usloviyakh tsifrovizatsii mirovogo razvitiya // Kontury global'nykh transformatsij: politika, ehkonomika, pravo. 2020. T.13. № 2. S. 177-194.

2. Brodovskaya E.V. TSifrovye grazhdane, tsifrovoe grazhdanstvo i tsifrovaya grazhdanstvennost' // Vlast'. 2019. T. 27. № 4. S. 65-69.

3. Volodenkov S.V. Transformatsiya sovremennykh politicheskikh protsessov v usloviyakh tsifrovizatsii obshhestva: klyuchevye stsenarii // Kontury global'nykh transformatsij: politika, ehkonomika, pravo. 2020. T.13. № 2. S. 6-24.

4. Gajvoronskaya YA.V. TSifra, kul'tura i vybory // Predstavitel'naya vlast' - XXI vek: zakonodatel'stvo, kommentarii, problemy. 2021. № 3(186). S. 24-28.

5. TSifrovoe budushhee gosudarstvennogo upravleniya po rezul'tatam / E.I. Dobrolyubova, V.N. YUzhakov, A.A. Efremov [i dr.]. M.: «Delo» RANKHiGS, 2019. $114 \mathrm{~s}$.

6. Dobrolyubova E.I. Otsenka tsifrovoj zrelosti gosudarstvennogo upravleniya // Informatsionnoe obshhestvo. 2021. № 2. S. 37-52.

7. Ignatovskij YA.R. Rol' tsifrovizatsii $\mathrm{v}$ transformatsii rossijskogo politicheskogo protesta // Vlast'. 2021. T. 29. № 1. S. 84-89. DOI: 10.31171/vlast.v29i1.7917

8. Indeks «TSifrovaya Rossiya». - Tekst: ehlektronnyj // Biznes-shkola upravleniya SKOLKOVO: [sajt]. URL: https://www.skolkovo.ru/researches/indeks-cifrovaya-rossiya/ (data obrashheniya: 18.08.2021).

9. Kon'kov A.E. Politicheskij diskurs v usloviyakh rasshireniya tsifrovogo prostranstva // Rossiya: tendentsii i perspektivy razvitiya. 2019. №14-1. S. 119-121.

10. Konyaeva T.V. Issledovanie regional'nykh disproportsij v razvitii tsifrovoj ehkonomiki Privolzhskogo federal'nogo okruga // EHkonomika i biznes: teoriya i praktika. 2019. № 7. C. 76-80. DOI: 10.24411/2411-0450-2019-11080.

11. Korovkin V.V. Natsional'nye programmy tsifrovoj ehkonomiki stran Blizhnego Vostoka // ArsAdministrandi. 2019. T. 11. № 1. S. 151-175. DOI: 10.17072/2218-91732019-1-151-175.

12. Reaktivnye sotsial'nye i politicheskie vzaimodejstviya $\mathrm{v}$ innovatsionnykh protsessakh regionov Rossii / E.A. Kranzeeva, E.V. Golovatskij, A.V. Orlova [i dr.] // Vlast' i upravlenie na Vostoke Rossii. 2021. № 2 (95). S. 86-102. DOI: 10.22394/1818-4049-2021-952-86-102.

13. Lapidus L.V. Analiz metodik otsenki urovnya tsifrovizatsii cherez prizmu prioritetnosti dlya razvitiya rossijskikh regionov // Mezhdunarodnaya ezhegodnaya nauchnaya konferentsiya Lomonosovskie chteniya-2019. Sektsiya ehkonomicheskikh nauk. EHkonomicheskie otnosheniya $\mathrm{v}$ usloviyakh tsifrovoj transformatsii: sbornik tezisov vystuplenij / pod red. M. V. Artamonova, S. N. Bobylev, G. I. Bryalina [i dr.]. M., 2019. T. 1. S. 6-9.

14. Lopatova N. Mezhdunarodnyj opyt formirovaniya tsifrovogo pravitel'stva // Nauka i innovatsii. 2019. № 5. S. 24-28.

15. Malysheva G.A. O sotsial'no-politicheskikh vyzovakh i riskakh tsifrovizatsii rossijskogo obshhestva // Vlast'. 2018. № 1. S. 40-46.

16. Mamychev A.YU., Petrova D.A. Biopoliticheskie i tsifrovye tendentsii razvitiya politiko-pravovykh praktik v period pandemii // Territoriya novykh vozmozhnostej. Vestnik Vladivostokskogo gosudarstvennogo universiteta ehkonomiki i servisa. 2020. T. 12. № 4. S. 18-29. DOI: 10.24866/VVSU/2073-3984/2020-4/018-029.

17. Mamychev A.YU., Frolova E.E., Kim A.A. «Budushhee» kak attraktor sovremennykh politiko-pravovykh i sotsial'no- ehkonomicheskikh transformatsij: obzor osnovnykh problem i podkhodov // Advances in Law Studies. 2020. Vol. 8: Special issue. P. 3-17. 
18. Mushta A.A., Rastimeshina T.V. Informatsionno-analiticheskaya kompetentnost' v konture gosudarstvennogo upravleniya: problemnye aspekty i puti sovershenstvovaniya // EHkonomicheskie i sotsial'no-gumanitarnye issledovaniya. 2019. № 2 (22). S. 147-154.

19. O Strategii razvitiya informatsionnogo obshhestva v Rossijskoj Federatsii na 2017-2030 gody: Ukaz Prezidenta Rossijskoj Federatsii ot 9 maya 2017 g. № 203. - Tekst: ehlektronnyj // SPS Konsul'tantPlyus: [sajt]. URL: http://www.consultant.ru/document/ cons_doc_LAW_216363/(data obrashheniya:20.08.2021).

20. Ōb otsenke ehffektivnosti deyatel'nosti vysshikh dolzhnostnykh lits (rukovoditelej vysshikh ispolnitel'nykh organov gosudarstvennoj vlasti) sub"ektov Rossijskoj Federatsii i deyatel'nosti organov ispolnitel'noj vlasti sub"ektov Rossijskoj Federatsii: Ukaz Prezidenta $\mathrm{RF}$ ot 4 fevralya 2021 g. № 68. - Tekst: ehlektronnyj // Ofitsial'nyj internet-portal pravovoj informatsii. URL: http://publication.pravo.gov.ru/Document/View/0001202102040027?index=0\&rangeSize=1 (data obrashheniya: 20.08.2021).

21. Ob utverzhdenii Natsional'noj programmy sotsial'no-ehkonomicheskogo razvitiya Dal'nego Vostoka na period do 2024 g. i na perspektivu do 2035 g.: rasporyazhenie Pravitel'stva RF ot 24 sentyabrya 2020 g. № 2464-r. - Tekst: ehlektronnyj // GARANT.RU: [sajt]. URL: https://www.garant.ru/products/ipo/prime/doc/74587526/ (data obrashheniya: 20.08.2021).

22. Ob utverzhdenii programmy «TSifrovaya ehkonomika Rossijskoj Federatsii»: rasporyazhenie Pravitel'stva Rossijskoj Federatsii ot 28 iyulya 2017 g. № 1632-r. - Tekst: ehlektronnyj // GARANT.RU: [sajt]. URL: http://base.garant.ru/71734878/(data obrashheniya: 20.08.2021).

23. Ob utverzhdenii Strategii sotsial'no-ehkonomicheskogo razvitiya Dal'nego Vostoka i Bajkal'skogo regiona na period do 2025 goda: rasporyazhenie Pravitel'stva RF ot 28 dekabrya 2009 goda № 2094-r. - Tekst: ehlektronnyj // GARANT.RU: [sajt]. URL: https:// www.garant.ru/products/ipo/prime/doc/6632462/ (data obrashheniya: 20.08.2021).

24. Pavlyutenkova M.YU. EHlektronnoe pravitel'stvo vs tsifrovoe pravitel'stvo v kontekste tsifrovoj transformatsii. - Tekst: ehlektronnyj // Monitoring obshhestvennogo mneniya: EHkonomicheskie i sotsial'nye peremeny. - 2019. № 5. S. 120-135. DOI: 10.14515/monitoring.2019.5.07

25. Rodionova I.A., Kokujtseva T.V., KHarlamov M.M. Osobennosti razvitiya tsifrovizatsii v Rossijskoj Federatsii i v razvitykh stranakh mira: analiz pozitsij v mezhdunarodnykh rejtingakh // EHkonomicheskie otnosheniya. 2020. T. 10. № 2. S. 381-394. DOI: 10.18334/eo.10.2.110130.

26. Rozhdestvenskaya I.A. TSifrovaya zrelost' rossijskikh regionov: problemy otsenki // Samoupravlenie. 2021. № 3 (125). S.553-555.

27. Savina S.V. Razvitie tsifrovykh tekhnologij v Rossii // Samoupravlenie. 2021. №2 (221). S.445-449.

28. Sal'nikov I.A., Varyukhin V.V., Malakhova YU.A. Novaya strategiya razvitiya informatsionnogo obshhestva v Rossii: novye tekhnologii, novye trebovaniya, novye perspektivy // Uchenye zapiski Sankt-Peterburgskogo imeni V. B. Bobkova filiala Rossijskoj tamozhennoj akademii. 2017. № 2 (62). S. 118-124.

29. Solov'eva N. V. Strategiya razvitiya informatsionnogo obshhestva kak osnova formirovaniya edinogo informatsionnogo prostranstva // Pravo i gosudarstvo: teoriya i praktika. 2019. № 4. S. 104-109.

30. Sukharev O.S. Otsenka institutov regional'nogo razvitiya i ehffektivnosti ispolnitel'noj vlasti sub"ektov Rossijskoj Federatsii. - Tekst: ehlektronnyj // Federalizm. 2021. № 2. S. 43-64. DOI: 10.21686/2073-1051-2021-2-43-64.

31. Tyushnyakov V.N. TSifrovaya transformatsiya sub"ektov Rossijskoj Federatsii // Upravlenie v ehkonomicheskikh i sotsial'nykh sistemakh: ehlektronnyj nauchnyj zhurnal. 2020. № 2 (4). S. 41-46. URL: http://www.journal-mes.ru (data obrashheniya: 22.08.2021).

32. Fomicheva T.V., Kataeva V.I. TSennosti rossiyan v kontekste tsifrovizatsii rossijskoj ehkonomiki // Uroven' zhizni naseleniya regionov Rossii. 2019. № 2(212). S. 80-84.

33. TSifrovaya ehkonomika RF. - Tekst: ehlektronnyj // Ministerstvo tsifrovogo razvitiya, svyazi i massovykh kommunikatsij Rossijskoj Federatsii: [sajt]. URL: https://digital. gov.ru/ru/activity/directions/858/ (data obrashheniya: 19.08.2021).

34. CHeremnykh V.YU., YAkovlev L.S. EHlektronnoe pravitel'stvo: modeli i perspektivy // Vestnik PAGS. 2017. №1. S. 68-74.

35. SHestopal S.S., Mamychev A.YU. Suverenitet v global'nom tsifrovom izmerenii: sovremennye trendy // Baltijskij gumanitarnyj zhurnal. 2020. T. 9. № 1(30). S. 398-403. DOI: 10.26140/bgz3-2020-0901-0098.

36. SHpakova A.A., Goryunova S.A. Strategicheskie programmy po tsifrovizatsii ehkonomiki YUzhnoj Korei // ArsAdministrandi (Iskusstvo upravleniya). 2021. T. 13. № 2. S. 260-284. DOI: 10.17072/2218-9173-2021-2-260-284.

37. Hudson V.M. Artificial Intelligence and International Politics. New York: Routledge, 2019. 422 p. DOI: $10.4324 / 9780429033575$.

38. Momeni M.A., Yaghoubi S., Aliha M.R.M. An Optimal Control Model for Analyzing Quality Investment in the Project Management // Computers \& Industrial Engineering. 2019. Vol. 129. R. 529-544. 
Потанина О. В. Цифровая трансформация политических отношений на Дальнем Востоке: проблемы и перспективы.

В данной статье рассматривается сущность политики региона в эпоху цифровизации. С появлением новейших цифровых технологий остро стоят вопросы их внедрения, цифрового предложения и спроса, измерения цифровизации. Благодаря применению новейших технологий происходит цифровая трансформация всех сфер жизни общества. Актуальность статьи состоит в рассмотрении цифровизации регионального уровня на примере Дальнего Востока России. В результате работы при рассмотрении данных индекса "Цифровая Россия" были изучены диспропорции в уровне цифровизации субъектов Дальневосточного федерального округа, которые могут быть устранены благодаря разработкам и реализации проектов, поставленных задач для достижения цели. Выявлены среднесрочные перспективы ДФО, делается вывод о том, что уровень цифровизации страны напрямую зависит от индекса цифровой трансформации регионов.

Ключевые слова: иифровизация, иифровые технологии, Дальневосточный фьедеральный округ России, государственная политика, иифбровая трансфборлация, регион.

Potanina O. V. Digital transformation of political relations in the Far East: problems and prospects.

This article discusses the essence of the policy of the region in the era of digitalization. With the advent of the latest digital technologies, the issues of their implementation, digital supply and demand, and the measurement of digitalization are acute. Thanks to the introduction of the latest technologies, a digital transformation of all spheres of society is taking place. The relevance of the article is to consider digitalization of the regional level on the example of the Russian Far East. As a result of the work, when considering the data of the Digital Russia index, imbalances in the level of digitalization of subjects of the Far Eastern Federal District were studied, which can be eliminated thanks to the development and implementation of projects set tasks to achieve the goal. Medium-term prospects of the Far Eastern Federal District have been identified, it is concluded that the level of digitalization of the country directly depends on the index of digital transformation of the regions.

Key words: digitalization, digital technologies, Far Eastern Federal District of Russia, state policy, digital transformation, region

Для цитирования: Потанина О. В. Цифровая трансформация политических отношений на Дальнем Востоке: проблемы и перспективы // Ойкумена. Регионоведческие исследования. 2021. № 4. C. 39-48. DOI: 10.24866/1998-6785/2021-4/39-48

For citation: Potanina O. V. Digital transformation of political relations in the Far East: problems and prospects // Ojkumena. Regional researches. 2021. № 4. P. 39-48. DOI: $10.24866 / 1998-6785 / 2021-4 / 39-48$ 